\title{
Green and Dry Forage Yields of Alfalfa"Medicago sativa, L." Populations Subjected to Selection Cycles for Glyphosate Tolerance
}

\author{
M. Abd El- Sattar Ahmed ${ }^{1 *}$, Ahlam, H. Mostafa ${ }^{2}$, Thanaa. I. Milad ${ }^{3}$ \\ and T.A. Mahmoud ${ }^{4}$ \\ 1 Professor, Crop Science Dept., Fac.Agric. (El-Shatby), Alexandria University (mohamed.a@alexu.edu.eg) \\ 2 Researcher, forage crops section, ARC, Nubaria, Egypt. \\ 3 Professor, Crop Science Dept., Fac.Agric. (El-Shatby), Alexandria University. \\ 4 Head Research, Forage Crops Section, ARC, Nubaria, Egypt. \\ *; corresponding author.
}

\begin{abstract}
The recent study was an attempt to measure the influence of selection for glyphosate tolerance in alfalfa germplasm on green and dry forage yields. Two cycles of recurrent selection for Glyphosate tolerance were imposed on each of five base population. Evaluation of selected cycles $\left(\mathrm{C}_{1}\right.$ and $\left.\mathrm{C}_{2}\right)$ along with base populations $\left(\mathrm{C}_{0}\right)$ was carried out for each population as a split plot design with Glyphosate treatment (+ and -) as main plots and populations $\left(\mathrm{C}_{0}, \mathrm{C}_{1}\right.$ and $\left.\mathrm{C}_{2}\right)$ as a sub - plot. The recorded dry forage yield from the studied population was similar irrespective of glyphosate treatment. Meanwhile, green, and dry forages of studied population, significantly varied $(p \geq 0.01)$ in ranke or magnitude depending on selection cycle (significant population $\times$ selection cycle interaction). In addition, green forage yields of glyphosate treatments significantly varied $(\mathrm{p} \geq 0.05)$ among populations and selection cycles (significant glyphosate treatment $\times$ population $\times$ selection cycle).The least green forage yield resulted from C.U.F. 101population when treated with glyphosate (110.32 ton.ha ${ }^{-1}$ ). That was not significantly different from green forage yields produced by any of Baladi land Siwa populations under glyphosate treatment. The highest significant green forage yields were obtained from any of Siriver or Baladi 1 population without glyphosate treatment (194.12 and 142.77 tons. $^{-1}$ for the former and the latter, respectively). On another words, the most sensitive population to glyphosate treatment in terms of green forage yield was Baladi 1, since, it produced the least green forage yield with glyphosate application (110.91 tons.ha $\left.{ }^{-1}\right)$ versus significantly the highest green forage yield without glyphosate application $\left(192.77\right.$ tons.ha $\left.^{-1}\right)$.The least green forage yield resulted from C.U.F. 101population when treated with glyphosate (110.32 ton.ha $\left.{ }^{-1}\right)$. That was not significantly different from green forage yields produced by any of Baladi land Siwa populations under glyphosate treatment.Response of dry forage yield to population $\times$ selection cycles interaction took similar pattern to what noticed in green forage yield. C.U.F. 101 showed a significant reduction of $10.26 \%$ in dry forage yield of cycle two relative to cycle one. While, Hasawi population, recorded a significant increase in dry forage yield of $15.52 \%$ with the second cycle of selection relative to cycle one. Siwa population, showed lowering in dry forage yield with one cycle of selection for glyphosate tolerance $(-7.373 \%)$ and an increase of $6.998 \%$ at second cycle of selection relative to cycle one.
\end{abstract}

Keywords: Selection, Glyphosate Tolerance, Green Forage, Dry Forage, Alfalfa .

\section{INTRODUCTION}

The registration of the new alfalfa variety Roundup Ready ${ }^{\circledR}$ started by mid-2005. The new variety came-up after the translocation of resistancegene to alfalfa germplasm. That enable the new plant to resist the effects of general eradication herbicide "glyphosate". The good consequences of adopting such new type of cultivars includes an improvement in yield, quality and turn- over. Also, glyphosate is a shortdurated herbicide in soil, with very limited influences on soil Flora and Fauna, beside,safe- effect on mammals. The bad cide in adopting cide-tolerant alfalfa cultivar is the shift in weed communities with rise proportion of tolerant species. Miller et al. (2006), summarized the benefits of using Roundup Ready (®) alfalfa in North states as; 1) better control of noxious- weed species, 2) insure less botanical injury- indicators, 3) Provide flexible management practice regarding the time of application, previelling weather, 4) reduce weed competition allowing fore better establishment and good forage quality, 5) ensure the use of pre- tested safe- herbicide, and 6) secure high quality hay freefrom noxious weeds. The expected increase in yield with this new technology reached about 1.4 to 3.3 ton. acre $^{-1}$ Late application of glyphosate to alfalfa Fields caused a reduction in yield reached 0.3 to 0.8 ton. $\mathrm{ha}^{-1}$.

Glaspieet al.(2011). Insured the value of introducing glyphosate- resistant alfalfa to cropping systems. They related its value to the required seedingrate, yield and quality of forage. From an experiment during two years on the relation between using glyphosate- resistant alfalfa cultivar, seeding rates and weed control programs, they emphasized the positive 
role using such cultivars. Orloff and Putnam (2011). Discussed the good and bad consequences of used roundup ready alfalfa cultivar. Growers of alfalfa at majority were satisfied with good consequences of new cultivar. They related their acceptance to this new cultivar to good limitation of weed competition, flexible application, and potentiality of culminating bad weeds. They also reported a higher forage yield and betterquality forage.

Beside the new glyphosate- tolerance gene that was adopted to alfalfa, another gene "Harvxtra" was introduced to a new germplasm (FONSI; USDAAPHIS, 2014). Acceptance of both engineered characters by farmers now a day still doubtful.

Daniel etal. (2016). Considered the situation for genetically engineered alfalfa cultivars in countries that don't permits the use of such genotypes, because of organic crop production. They noted that farmers might produce non- genetically engineered hay for sensitive markets and engineered hay for non- sensitive markets. Miller etal. (2016). Considered the contribution of using roundup ready alfalfa to weed management in fields. The studied treatments included glyphosate doses and timing. They also- included the standard control means. They reached an increase in yield with increasing seeding rate and with applying glyphosate. Forage quality insignificantly affected by any of the studied treatments. Boerboom et al.(1991), evaluated birds-foot trefoil after glyphosate treatment. Their results showed that, shoot weight of the three studied cycle-two populations were about 44 to $85 \%$ greater than base population, indicating increased glyphosate tolerance. Regrowth of trefoil showed an increase in weight reached 44 to $127 \%$ in cycle two populations. Miller et al.(2006), recorded an increases in herbicidetreated plots ranged from 1.4 to 3.3 tons per acre. They added that, alfalfa yields were highest in glyphosatetreated plots, where, weeds were removed at the twotrifoliate leaf stage of alfalfa or earlier. Delaying glyphosate application until four-trifoliate late leaf stage reduced alfalfa yields by 0.3 to 0.8 ton/acre. They added that, alfalfa yields were 0.1 lower to 0.9 higher (ton/acre) in glyphosate-treated plots. Glaspie et al.(2011), found that, alfalfa yield was greater when treated with glyphosate. Zobiole et al.(2011), reached that,glyphosate treatment reduced yield components such as photosynthesis, water absorption, nutrient uptake and symbiotic nitrogen fixation in glyphosatetolerant soybean cultivars. They added that, data that explain the effect of glyphosate on physiology of soybean is lacking.

Research results regarding the consequences of improving alfalfa tolerance to glyphosate in Egypt is relatively scare. The recent study was an attempt to measure the influence of selection for glyphosate tolerance in alfalfa germplasm on green and dry forage yields under glyphosate treatments (+ / -).

\section{MATERIALS AND METHODES}

Alfalfa plant materials (Medicago sativa,L.) used in that recent study will be referred to five base populations. Two cycles of recurrent selection for Glyphosate tolerance were imposed on each base population. Each cycle of selection within a base germplasm is hereafter referred to as a population.

C.U.F 101 population Pedigree was (University of California Davis, UC 76, 1972, released by C.U.F seed company). Siriver population (Hunter river $\mathrm{x}$ C.U.F 101 and UC 110 and UC 112),.Hasawi population is a land race naturally originated on Saudi Arabia. Baldi1 population Selected from ELWadi EL-Gedid landrace by Forage Research Department of ARC, Egypt. Siwa population is a land race naturally originated on Siwa Oasis of western-desert, Egypt.

Cycle one was practiced on 2800 plants per each base population $\left(\mathrm{C}_{0}\right)$. Base populations were seeded at density of 100 plant. $\mathrm{m}^{-2}$ (considering seed index and germination percentages). Each germplasm seeded in $28 \mathrm{~m}^{2}$ (20 rows of $1.75 \mathrm{~m}$ long and $0.80 \mathrm{~m}$ apart) on Nubaria Agricultural Research Station, North of Egypt. Seeding date was, May $27^{\text {th }}$, 2015 . Four weeks after seeding, plants $(8-15 \mathrm{~cm}$ tall $)$ were treated with $0.56 \mathrm{~kg}$ acid equivalent per hectare (ae. ha ${ }^{-1}$ ) of Glyphosate (Round up $®$ ) diluted in 480 liter of water (L). Survived plants were left to complete the first cutting growth (two months). Regrowth of the second cutting at $20-25 \mathrm{~cm}$ height was sprayed by $0.84 \mathrm{~kg}$ ae. ha ${ }^{-1}$ glyphosate in $480 \mathrm{~L}$ water. ha ${ }^{-1} .14$ day after treatment, plants was rated for injury on a 1 to 4 scale (where $1=$ uninjured, $2=$ injured shoot, $3=$ dead shoot with live auxiliary shoots and 4= dead seeding) (Boerboom et al. 1991). The uninjured plants were selected uprooted and transplanted to an isolated plots surrounded and covered by insect proof cloth for flowering and seed setting .Plants selected for Glyphosate tolerance from each germplasm were 100 plant .Each germplasm was caged separately in cloth house and a portable honey bees heave (Apis mellifera, L.) was used as pollinators (for random matting among plants). Seeds were harvested for each separate plant as a half-sib family on June, $15^{\text {th }}$,2016.Equale seed weight from each selected half-sib family seeds were bulked to from first improved cycle $\left(\mathrm{C}_{1}\right)$. The second cycle of selection was practiced for each 
separate improved population. Each population was seeded in 20 rows of $1.25 \mathrm{~m}$. long and $0.80 \mathrm{~m}$ apart (2000 plant). Four-week-old seedlings were treated with Glyphosate at $0.56 \mathrm{~kg}$ ae. $\mathrm{ha}^{-1}$ in 480 liters of water. Fourteen days after treatment, injury levels were rated as $1=$ uninjured, $2=$ injured shoot, $3=$ dead shoot with live auxiliary shoots and $4=$ dead seeding. The uninjured plants were selected uprooted and transplanted to an isolated plot surrounded and covered by insect proof cloth for flowering and seed setting. Plants selected for Glyphosate tolerance from each germplasm were 100 plant. Each germplasm was caged separately in cloth house and a portable honeybees heave (Apis mellifera L.) was used as pollinators (for random matting among plants). Seeds were harvested for each separate plant as a half-sib family on June $15^{\text {th }}$, 2017.Equale seed weight from each selected half-sib family seeds were bulked to from second improved cycle $\left(\mathrm{C}_{2}\right)$.

Evaluation of selected cycles $\left(\mathrm{C}_{1}\right.$ and $\left.\mathrm{C}_{2}\right)$ along with base populations $\left(\mathrm{C}_{0}\right)$ was carried out for each population as a split plot design with Glyphosate treatment (+ and -$)$ as main plots and populations $\left(\mathrm{C}_{0}, \mathrm{C}_{1}\right.$ and $\left.\mathrm{C}_{2}\right)$ as a sub -plot. Four replicates were used. Plot size was three rows of $1.80 \mathrm{~m}$ long and $0.15 \mathrm{~m}$ apart. Planting of seeds took place at November $1^{\text {st }}$, 2017. Glyphosate treatment was applied 30 days after planting at $0.84 \mathrm{~kg}$ ae. $\mathrm{ha}^{-1}$ in 480 liters of water. Glyphosate treated and untreated plots were evaluated for the following characters:

1- Green forage yield (ton per hectare): total plots were harvested weighted and transformed to ton. hectare $^{-1}$, prior to statistical analysis. Data were recorded for ten cuttings.
2- Dry forage yield (ton per hectare): determined from dry matter percentage and green forage yield of each plot.

Data of all experiments were subjected to analysis of variance according to Cochran and Cox, 1957. Means were separated by a protected L.S.D. test (Fisher, 1960). Mstat-c package was used in all analysis.

\section{RESULTS AND DISCUSSION}

Response of alfalfa populations (five populations) and selection cycles to glyphosate tolerance (three cycles) under presence and absence of glyphosate treatment (+ and -) in terms of green and dry forage yields were illustrated in Table 1. Over populations and selection cycles, variable $(\mathrm{p} \geq 0.01)$ green and dry forage yields were recorded with presence or absence of glyphosate treatments. Also, the studied population gave different $(p \geq 0.05)$ green forage yields. That was not true for dry forage yields that were significantly similar. In the meantime the obtained green forage yield from the studied populations significantly varied ( $\mathrm{p} \geq 0.01$ ) depending on glyphosate treatment ( + or - ) (significant glyphosate treatment $\times$ population interaction). While, the recorded dry forage yield from the studied population was similar irrespective of glyphosate treatment. Meanwhile, green and dry forages of studied population, significantly varied $(\mathrm{p} \geq 0.01)$ in ranke or magnitude depending on selection cycle (population $\times$ selection cycle interaction). In addition, green forage yields of glyphosate treatments significantly varied $(\mathrm{p} \geq 0.05)$ among populations and selection cycles (significant glyphosate treatment $\times$ population $\times$ selection cycle). The latter was not true in case of dry forage yields.

Table (1): Mean squares of green and dry forage yields for alfalfa population as affected by glyphosate treatments and selection for glyphosate tolerance.

\begin{tabular}{|l|l|l|l|}
\hline \multirow{2}{*}{ S.O.V } & \multirow{2}{*}{ d.f. } & \multicolumn{2}{|c|}{ M.S } \\
\cline { 3 - 4 } & & Green forage yield & \multicolumn{1}{c|}{ Dry forage yield } \\
\hline Glyphosate treatment $(\mathrm{G})$ & 1 & $153498^{* *}$ & $6667^{* *}$ \\
Rep /Glyphosate & 3 & 852.3 & 61.65 \\
\hline Population (P) & 4 & $361.9^{*}$ & $13.53^{\text {n.s. }}$ \\
GXP & 4 & $425.3^{* *}$ & $20.62^{\text {n.s. }}$ \\
Selection cycle (S) & 2 & $263.9^{\text {n.s. }}$ & $21.91^{\text {n.s. }}$ \\
GXS & 2 & $184.5^{\text {n.s. }}$ & $15.44^{\text {n.s. }}$ \\
PXS & 8 & $1048^{* *}$ & $76.79^{* *}$ \\
GXPXS & 8 & $233.9^{*}$ & $11.39^{\text {n.s. }}$ \\
Error & 84 & 103 & 7.425 \\
\hline
\end{tabular}

${ }^{*},{ }^{* *}$ significant at 0.05 and 0.01 levels of probability, respectively.

${ }_{\text {n.s }}$ not significantly different at 0.05 level of probability. 
Means of green and dry forage yields for the three studied main factors, i.e; glyphosate treatment, population and selection cycle were illustrated in Table (2). Glyphosate untreated selection cycles in all studied populations gave 1.617 and 1.586 times higher green and dry forage yields (187.4 vs. 115.9 and 40.34 vs. 25.43 tons.ha $^{-1}$ green and dry forages, respectively). Also, Siriver population significantly gave the highest green forage yield of 157.3tons.ha ${ }^{-1}$. Meanwhile, the other studied alfalfa populations gave similar green forage yield. Over glyphosate treatments and populations, selection cycles for glyphosate tolerance gave similar green and dry forage yields, since, the improvement in yields due to selection failed to reach the level of significance.

Table (2): Mean of forage yield for Glyphosate traded, alfalfa base population selection cycles

\begin{tabular}{|c|c|c|c|}
\hline Factors & Level of factor & Green forage yield(t.ha $\left.{ }^{-1}\right)$ & Dry forage yield t.ha ${ }^{-1}$ ) \\
\hline \multirow{2}{*}{ Glyphosate } & Treated & 115.9 & 25.43 \\
\hline & Untreated & 187.4 & 40.34 \\
\hline \multicolumn{2}{|l|}{ L.S.D 0.05} & 13.04 & 3.507 \\
\hline \multirow{5}{*}{ Population } & C.U.F 101 & 148.3 & 32.35 \\
\hline & Hasawi & 153.1 & 33.71 \\
\hline & Siravar & 157.3 & 33.31 \\
\hline & Baladi 1 & 151.8 & 33.18 \\
\hline & Siwa & 147.8 & 31.88 \\
\hline \multicolumn{2}{|l|}{ L.S.D 0.05} & 5.800 & n.s \\
\hline \multirow{3}{*}{$\begin{array}{l}\text { Selection } \\
\text { cycles }\end{array}$} & $\mathrm{C}_{0}$ & 149.5 & 32.39 \\
\hline & $\mathrm{C}_{1}$ & 154.5 & 33.74 \\
\hline & $\mathrm{C}_{2}$ & 150.9 & 32.52 \\
\hline \multicolumn{2}{|l|}{ L.S.D 0.05} & n.s & n.s \\
\hline
\end{tabular}

${ }^{\text {n.s. }}$; not significantly different.

L.S.D. 0.05 ; least significant difference at 0.05 levels.

Forage yields (green and dry) as affected by the first order interaction between population and glyphosate treatment were presented in Table (3). The least green forage yield resulted from C.U.F. 101population when treated with glyphosate $(110.32$ ton.ha $\left.{ }^{-1}\right)$. That was not significantly different from green forage yields produced by any of Baladi land Siwa populations under glyphosate treatment. While, the highest significant green forage yields were obtained from any of Siriver or Baladi 1 population without glyphosate treatment. (194.12 and 142.77 tons.ha ${ }^{-1}$ for the former and the latter, respectively). On anther words, the most sensitive population to glyphosate treatment in terms of green forage yield was Baladi 1, since, it produced the least green forage yield with glyphosate application (110.91 tons.ha ${ }^{-1}$ ) versus significantly the highest green forage yield without glyphosate application (192.77 tons.ha $\left.{ }^{-1}\right)$. This clearily indicate a reduction associated with glyphosate application reached $42.47 \%$. Dry forage yield was affected by population $\times$ glyphosate treatment in similar manner. The least significant dry forage yields were produced by any of C.U.F101, Baladi 1 and Siwa population when treated by glyphosate $(24.58,24.63$ and 24.47 tons.ha $^{-1}$ for the three successive populations, respectively). While, the highest significant dry forage yields were those of Baladi 1 population without glyphosate treatment (41.73 ton.ha ${ }^{-1}$ ). In the meantime, Baladi 1 population might be considered as the most vulnearable to glyphosate treatment in terms of dry forage yield with areduction rate reached $41.98 \%$ due to glyphosate treatment. 
Table (3): Means of green and dry forage yields as affected by the interaction betweenAlfalfa populations and glyphosate treatment

\begin{tabular}{|c|c|c|c|c|}
\hline \multirow[b]{2}{*}{ Population } & \multicolumn{2}{|c|}{ Green forage yield (t. ha $\left.{ }^{-1}\right)$} & \multicolumn{2}{|c|}{ Dry forage yield (t. ha-1) } \\
\hline & Treated & Untreated & Treated & Untreated \\
\hline C.U.F 101 & 110.32 & 186.25 & 24.58 & 40.12 \\
\hline Hasawi & 122.76 & 183.42 & 27.72 & 39.71 \\
\hline Sirivar & 120.54 & 194.12 & 25.75 & 40.86 \\
\hline Baladi 1 & 110.91 & 192.77 & 24.63 & 41.73 \\
\hline Siwa & 115.01 & 180.63 & 24.47 & 39.29 \\
\hline L.S.D 0.05 & \multicolumn{2}{|c|}{8.203} & \multicolumn{2}{|c|}{2.202} \\
\hline
\end{tabular}

L.S.D.; least significant difference at 0.05 level of probability

Means of green and dry forage yields as affected by the interaction between alfalfa populations and selection cycles for glyphosate tolerance were shown in Table (4). Green forage yields of the studied population respond differently to selection cycles. C.U.F. 101 population recorded an increase with the first cycle of selection for glyphosate tolerance (2.499\%), along with reduction in green forage yield with the progress of selection to cycle two, relative to cycle one (-8.48\%). Those changes in green forage yield had not reached the level of significance. As for Hasawi population, selection for glyphosate selection for one and two cycles caused an increase in green forage yield (6.310and 9.982\% increase for cycle one and two relative to base and cycle one respectively). The yield increase that obtained in cycle two had reached the level of significance. Siriver population, recorded an increase in green forage yield with cycle one and two of selection reached 4.554 and $5.204 \%$ relative to the preceding cycles, respectively. Those increase, although, were sound had not reached the level of significance. Baladi 1 population, paradoxically, recorded an increase in green forage yield in cycle one of selection of $5.970 \%$ relative to the base population, along with a reduction of $20.20 \%$ for cycle two of selection, relative to cycle one. Siwa population, recorded insignificant change in green forage yield with selection cycles reached -2.689 and $+3.787 \%$ for cycle one and two relative to base and cycle one, respectively.

Table (4): Means of green and dry forage yields as affected by the interaction between alfalfa populations and selection cyclesfor glyphosate tolerance.

\begin{tabular}{|c|c|c|c|c|c|c|c|}
\hline \multirow{2}{*}{ Population } & \multirow{2}{*}{$\begin{array}{l}\text { Selection } \\
\text { cycle }\end{array}$} & \multirow{2}{*}{$\begin{array}{l}\text { Green forage } \\
\text { yield }\left(\text { t.hat }^{-1}\right)\end{array}$} & \multicolumn{2}{|c|}{ Relative to } & \multirow{2}{*}{$\begin{array}{l}\text { Dry forage } \\
\left.\text { yield (t.ha }{ }^{-1}\right)\end{array}$} & \multicolumn{2}{|c|}{ Relative to } \\
\hline & & & $\mathrm{C}_{0}$ & $\mathrm{C}_{1}$ & & $\mathrm{C}_{0}$ & $\mathrm{C}_{1}$ \\
\hline \multirow{3}{*}{ C.U.F 101} & $\mathrm{C}_{0}$ & 150.1 & & & 32.89 & & \\
\hline & $\mathrm{C}_{1}$ & 153.9 & $2.499^{\text {n.s. }}$ & & 33.82 & 2.816 & \\
\hline & $\mathrm{C}_{2}$ & 140.8 & & $-8.480^{*}$ & 30.34 & & $-10.26^{*}$ \\
\hline \multirow{3}{*}{ Hasawi } & $\mathrm{C}_{0}$ & 142.1 & & & 30.38 & & \\
\hline & $\mathrm{C}_{1}$ & 151.1 & $6.310^{\text {n.s. }}$ & & 32.84 & $8.081^{*}$ & \\
\hline & $\mathrm{C}_{2}$ & 166.1 & & $9.982^{*}$ & 37.93 & & $15.52^{*}$ \\
\hline \multirow{3}{*}{ Sirivar } & $\mathrm{C}_{0}$ & 150.1 & & & 32.13 & & \\
\hline & $\mathrm{C}_{1}$ & 156.9 & $4.554^{\text {n.s. }}$ & & 34.32 & $6.816^{*}$ & \\
\hline & $\mathrm{C}_{2}$ & 165.1 & & $5.204^{\mathrm{ns}}$ & 33.46 & & $-2.500^{\mathrm{ns}}$ \\
\hline \multirow{3}{*}{ Baladi 1} & $\mathrm{C}_{0}$ & 156.8 & & & 33.76 & & \\
\hline & $\mathrm{C}_{1}$ & 166.1 & $5.970^{\mathrm{ns}}$ & & 37.35 & $10.62^{*}$ & \\
\hline & $\mathrm{C}_{2}$ & 132.6 & & $-20.20^{*}$ & 28.43 & & $-23.87^{*}$ \\
\hline \multirow{3}{*}{ Siwa } & $\mathrm{C}_{0}$ & 148.7 & & & 32.78 & & \\
\hline & $\mathrm{C}_{1}$ & 144.7 & $-2.689^{\mathrm{ns}}$ & & 30.36 & $-7.373^{\mathrm{ns}}$ & \\
\hline & $\mathrm{C}_{2}$ & 150.1 & & $3.787^{\mathrm{ns}}$ & 32.49 & & $6.998^{\mathrm{ns}}$ \\
\hline L.S.D ${ }_{0.05}$ & & 10.04 & & & & 2.697 & \\
\hline
\end{tabular}

$\mathrm{C}_{0}$; base population. $\mathrm{C}_{1}$; cycle one of selection. $\mathrm{C}_{2}$; cycle two of selection. 
Response of dry forage yield to population $\times$ selection cycles interaction took similar pattern to wheat noticed in green forage yield. C.U.F. 101 showed a significant reduction of $10.26 \%$ in dry forage yield of cycle two relative to cycle one. While, Hasawi population, recorded a significant increase in dry forage yield of $15.52 \%$ with the second cycle of selection relative to cycle one. Baladi 1 population scored an increase of significant magnitude with the first cycle of selection for glyphosate tolerance $(10.62 \%$ relative to the base population), Whereas, in contrary a reduction of $23.87 \%$ in dry forage yield of cycle two relative to cycle one was realized. That reduction was significant. Siwa population, showed lowering in dry forage yield with one cycle of selection for glyphosate tolerance ($7.373 \%$ ) and an increase of $6.998 \%$ at second cycle of selection relative to cycle one.

Second order interactionamong alfalfa populations $\times$ selection cycles $\times$ glyphosate treatment for green forage yield was presented in Table (5). C.U.F. 101population after one cycle of selection for glyphosate tolerance gained insignificant increase of 0.691 and $3.687 \%$ of the respective base population yield when evaluated under glyphosate treatment and lack of glyphosate treatment, respectively. While, the second cycle of selection associated with a significant green forage yield reduction of $-15.33 \%$ relative to yield of preceding cycle, when evaluated under glyphosate treatment versus insignificant reduction of $4.288 \%$ relative to cycle one green forage yield when evaluated under glyphosate treatment. Hasawi population scored increases in green forage yield with the advancement of selection cycles, regardless of glyphosate treatment level (7.247 and $21.64 \%$ increase in first and second cycles green forage yield, relative of yield of previous cycle). The latter increase in green forage yield of second cycle was significant. Insignificant increase associated with progress of selection, reached 5.711 and $2.53 \%$ relative to base population and first cycle yields when evaluated under glyphosate treatment. Siriver population, showed insignificant increases with progress of selection for glyphosate tolerance irrespective of evaluation protocol (under glyphosate treatment or lack of treatment). Baladi 1 population, showed a bidirectional response in green forage yield to selection for glyphosate tolerance, since, the first cycle gave an increase reached 13.30 (significant) and 2.053 (insignificant) from evaluation under glyphosate treatment and lack of treatment, respectively, while, the second cycle had a significant decrease in green forage yield of -18.94 and $-20.93 \%$ relative to cycle one under glyphosate treatment and lacl of treatment, respectively. Responses of Siwa population were insignificant relative to base and cycle one of selection irrespective of glyphosate treatment.

Table (5): Mean of forage yield of interaction between alfalfa base populations and treated by Glyphosate

\begin{tabular}{|c|c|c|c|c|c|c|c|c|c|}
\hline \multirow{3}{*}{ Population } & \multirow{3}{*}{$\begin{array}{l}\text { Selection } \\
\text { cycle }\end{array}$} & \multicolumn{6}{|c|}{ Green forage yield $\left(t . h^{-1}\right)$} & \multicolumn{2}{|c|}{ Dry forage yield (t. ha $\left.{ }^{-1}\right)$} \\
\hline & & \multirow[t]{2}{*}{ Treated } & \multicolumn{2}{|c|}{ Relative to } & \multirow[t]{2}{*}{ Untreated } & \multicolumn{2}{|c|}{ Relative to } & \multirow[t]{2}{*}{ Treated } & \multirow[t]{2}{*}{ Untreated } \\
\hline & & & $\mathrm{C}_{0}$ & $\mathrm{C}_{1}$ & & $\mathrm{C}_{0}$ & $\mathrm{C}_{1}$ & & \\
\hline \multirow{3}{*}{ C.U.F 101} & $\mathrm{C}_{0}$ & 115.7 & & & 184.4 & & & 25.66 & 40.11 \\
\hline & $\mathrm{C}_{1}$ & 116.5 & $0.691^{\mathrm{ns}}$ & & 191.2 & $3.687^{\mathrm{ns}}$ & & 26.09 & 41.53 \\
\hline & $\mathrm{C}_{2}$ & 98.64 & & $-15.33^{*}$ & 183.0 & & -4.288 & 21.99 & 38.69 \\
\hline \multirow{3}{*}{ Hasawi } & $\mathrm{C}_{0}$ & 109.0 & & & 175.1 & & & 23.70 & 37.05 \\
\hline & $\mathrm{C}_{1}$ & 116.9 & $7.247^{\mathrm{ns}}$ & & 185.1 & $5.711^{\mathrm{ns}}$ & & 26.21 & 39.45 \\
\hline & $\mathrm{C}_{2}$ & 142.2 & & $21.64^{*}$ & 189.9 & & 2.53 & 33.24 & 42.61 \\
\hline \multirow{3}{*}{ Siravar } & $\mathrm{C}_{0}$ & 116.3 & & & 183.7 & & & 25.39 & 38.87 \\
\hline & $\mathrm{C}_{1}$ & 120.3 & $3.439^{\mathrm{ns}}$ & & 193.4 & $5.280^{\mathrm{ns}}$ & & 26.20 & 42.43 \\
\hline & $\mathrm{C}_{2}$ & 124.8 & & $3.740^{\mathrm{ns}}$ & 205.2 & & 6.101 & 25.66 & 41.26 \\
\hline \multirow{3}{*}{ Baladi 1} & $\mathrm{C}_{0}$ & 109.0 & & & 204.5 & & & 23.78 & 43.74 \\
\hline & $\mathrm{C}_{1}$ & 123.5 & $13.30^{*}$ & & 208.7 & $2.053^{\mathrm{ns}}$ & & 28.15 & 46.53 \\
\hline & $\mathrm{C}_{2}$ & 100.1 & & $-18.94^{*}$ & 165.0 & & -20.93 & 21.96 & 34.89 \\
\hline \multirow{3}{*}{ Siwa } & $\mathrm{C}_{0}$ & 111.8 & & & 185.4 & & & 23.71 & 41.84 \\
\hline & $\mathrm{C}_{1}$ & 110.8 & $-0.894^{\mathrm{ns}}$ & & 178.4 & $-3.775^{\mathrm{ns}}$ & & 23.66 & 37.05 \\
\hline & $\mathrm{C}_{2}$ & 122.3 & & $10.37^{\mathrm{ns}}$ & 177.9 & & -0.280 & 26.02 & 38.95 \\
\hline L.S.D ${ }_{0.05}$ & & \multicolumn{6}{|c|}{14.20} & \multicolumn{2}{|c|}{ n.s. } \\
\hline
\end{tabular}

n.s.; not significantly different 
The recent results might be considered in a comparison to other researchers results. Boerboom et al. (1991), evaluated birds-foot trefoil after glyphosate treatment. Their results showed that, shoot weight of the three studied cycle-two populations were about 44 to $85 \%$ greater than base population, indicating increased glyphosate tolerance. Regrowth of trefoil showed an increase in weight reached 44 to $127 \%$ in cycle two populations. Miller et al. (2006), recorded an increases in herbicide-treated plots ranged from 1.4 to 3.3 tons per acre. They added that, alfalfa yields were highest in glyphosate-treated plots, where, weeds were removed at the two-trifoliate leaf stage of alfalfa or earlier. Delaying glyphosate application until fourtrifoliate late leaf stage reduced alfalfa yields by 0.3 to 0.8 ton/acre. They added that, alfalfa yields were 0.1 lower to 0.9 higher (ton/acre) in glyphosatetreated plots. Glaspie et al. (2011), found that, alfalfa yield was greater when treated with glyphosate. Zobiole et al. (2011), reached that, glyphosate treatment reduced yield components such as photosynthesis, water absorption, nutrient uptake and symbiotic nitrogen fixation in glyphosate-tolerant soybean cultivars. They added that, data that explain the effect of glyphosate on physiology of soybean is lacking.

\section{In conclusion:}

- Over populations and selection cycles, variable $(\mathrm{p} \geq 0.01)$ green and dry forage yields were recorded with presence or absence of glyphosate treatments. Also, the studied population gave different ( $\mathrm{p} \geq 0.05$ ) green forage yields. That was not true for dry forage yields that were significantly similar. In the meantime, the obtained green forage yield from the studied populations significantly varied $(\mathrm{p} \geq 0.01)$ depending on glyphosate treatment (+ or -) (significant glyphosate treatment $\times$ population interaction). The recorded dry forage yield from the studied population was similar irrespective of glyphosate treatment. Meanwhile, green, and dry forages of studied population, significantly varied $(\mathrm{p} \geq 0.01)$ in ranke or magnitude depending on selection cycle (significant population $\times$ selection cycle interaction). In addition, green forage yields of glyphosate treatments significantly varied ( $\mathrm{p} \geq 0.05$ ) among populations and selection cycles (significant glyphosate treatment $\times$ population $\times$ selection cycle).

- The least green forage yield resulted from C.U.F. 101population when treated with glyphosate
(110.32 ton. ha $^{-1}$ ). That was not significantly different from green forage yields produced by any of Baladi land Siwa populations under glyphosate treatment. The highest significant green forage yields were obtained from any of Siriver or Baladi 1 population without glyphosate treatment. (194.12 and 142.77 tons. ha $^{-1}$ for the former and the latter, respectively). On another words, the most sensitive population to glyphosate treatment in terms of green forage yield was Baladi 1, since, it produced the least green forage yield with glyphosate application (110.91 tons.ha ${ }^{-1}$ ) versus significantly the highest green forage yield without glyphosate application (192.77 tons.ha ${ }^{-1}$ ).

- Response of dry forage yield to population $\times$ selection cycles interaction took similar pattern to wheat noticed in green forage yield. C.U.F. 101 showed a significant reduction of $10.26 \%$ in dry forage yield of cycle two relative to cycle one. While, Hasawi population, recorded a significant increase in dry forage yield of $15.52 \%$ with the second cycle of selection relative to cycle one. The first cycle of selection for glyphosate tolerance gave an increase $(10.62 \%$ relative to the base population), Whereas, in contrary a reduction of $23.87 \%$ in dry forage yield of cycle two relative to cycle one was realized. That reduction was significant. Siwa population, showed lowering in dry forage yield with one cycle of selection for glyphosate tolerance ($7.373 \%$ ) and an increase of $6.998 \%$ at second cycle of selection relative to cycle one.

\section{LITERATURE CITED}

Boerboom C.M, N.J, Ehlke D.L Wyse and D.A Somers. 1991. Recurrent selection for glyphosate tolerance in Birdsfoot Trefoil. Crop sci.31;1124-1129.

Daniel, H. P., T.Woodward, P.Reisen, and S.Orloff 2016. Coexistence and Market assurance for Production of non-genetically engineered alfalfa hay and forage in a biotech Era. Crop Forage Turfgrass Manage ( 2)1:13.

Fisher ,R.A. 1960. The Designs of Experiments. 7 th. Ed. Oliver\&Boyd, Edinburgh.

Glaspie C.F, S.A McCordick, T.S Dietz, J KellsJ., H.R Leep, and W.J Everman.2011. Effect of Seeding Rate and Weed Control on Glyphosate-Resistant Alfalfa Establishment. Weed Technology 25(2);230-238. Doi: http://dx.doi.org. 
Miller S.D, R.G, Wilson A.R Kniss and C.M.Alford 2006.Roundup Ready ${ }^{\circledR}$ Alfalfa A new technology for high plains hay producers. Jenna Norfolk, College of Agriculture intern.

Miller S.D. and. C.M. Alford 2016.Weed Control and Glyphosate Tolerant Alfalfa Response to Glyphosate Rate and Application Timing. (W-miller131842-oral).

MSTAT-C.(1996). Russel, D.Freed, MSTAT Director, Crop and soil Sciences Department, Michigan State University, U.S.A.

Muooz-Rueda A., C.Gonzalez-Murua, J.M. Becerril and M.F.Slnchez-Deaz 1986. Effects of

Orloff. S. and Putnam .D.2011.Roundup ready® alfalfa- what have we learned to date.Western
Alfalfa \& Forage Conference, http://alfalfa.ucdavis.edu.

Zobiole L. H. S, R.J Kremer, R. S. Oliveira and .J Constantin. 2011. Glyphosate affects chlorophyll, nodulation and nutrient accumulation of "second generation" glyphosate-resistant soybean (Glycine max, L.) a Pesticide Biochemistry and Physiology 99; 53-60.

ZobioleL.H.S , R.S. Oliveira Jr., R.J. Kremer, A.S. Muniz and A. Oliveira Jr.2010. Nutrient accumulation and photosynthesis in glyphosate resistant soybeans is reduced under glyphosate use. J. Plant. Nutr. 33; 1860-1873. 


\section{محصول العلف الاخضر والجاف لعثائر البرسيم الحجازى بعد دورات من الانتخاب لتحمل الجليفوسات}

محمد عبد الستار احمد و احلام حسنى مصطفى و سناء ابراهيم ميلاد و طه احمد محمود

الدراسة الحالية محاولة لقياس تأثير الأنتخاب لتحمل مبيد الجليفوسات في الوعاء الجيني للبرسيم الحجازي علي صفات محصول العلف الأخضر والجاف. تم تتفيذ دورتان من الأنتخاب الدوري لتحمل الجليفوسات في كل من خمس لأل عثائر اساس لتقييم ناتج الدورات مع عشائر الاساس اجريا منفصلاً لكل عشيرة في تصميم قطع منشقة حيث مثلت المعاملة بالجليفوسات(土) القطع الرئيسية الثانية بينما وضعت دورات الانتخاب (الاساس, الدورة الأولي, الدورة الثانية) في القطع المنشقة. قيم محصول العلف الجاف المسجلة للعشائر المدروسة كانت متماثلة بغض النظر عن المعاملة بالجليفوسات. في حين أن كل من محصول العلف الأخضر والجاف الناتج من العثائر المدروسة اختلفت في الترتيب أو في القيمة اعتماداً علي تطور دورات الأنتخاب (تفاعل معنوي بين العثائر ودورات الأنتخاب). يضاف إلي ذلك أن محصول العلف الأخضر للقطع المعاملة بالجليفوسات اختلف معنوياً بين العشائر المدروسة ودورات الأنتخاب (تفاعل معنوي بين المعاملة بالجليفوسات × العشيرة × دورة الأنتخاب). وقد نتج أقل محصول علف أخضر من عشيرة (C.U.F.101) النعاملة بالجليفوسات. أعلي محصول علف أخضر نتج عن اي من العشائر ساي ريفر أو بلدي ا بدون المعاملة

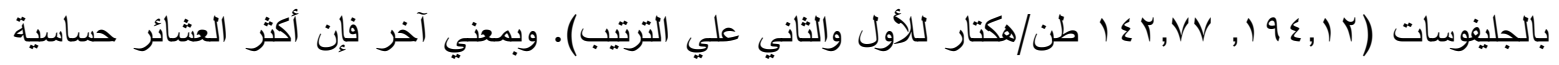
للمعاملة بالجليفوسات معبراً عن ذلك في صورة محصول علف أخضر كانت عثيرة بلدي ا حيث كانت أقل محصول علف أخضر عند المعاملة بالجليفوسات (19,9.911 طن/هكتار) في مقابل أعلي محصول علف أخضر بدون معاملة بالجليفوسات (9Y,VVV تحت ظروف المعاملة بالجليفوسات وقد أعطي محصول العلف الجاف استجابة مماثلة للعلف الأخضر لتفاعل العشيرة

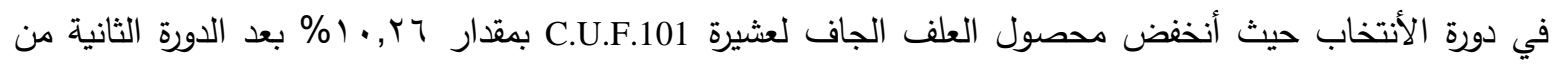

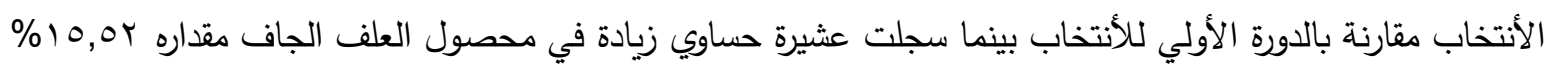

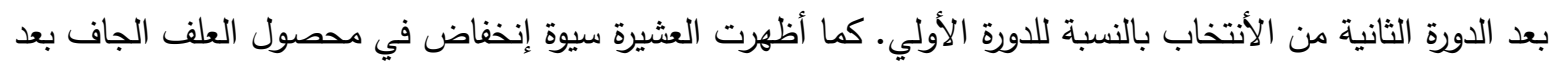
دورة واحدة من الأنتخاب لتحمل الجليفوسات (V,YVY) وزيادة بعد الدورة الثانية من الأنتخاب بلغت للدورة الأولي. 
Vol. 65, No. 1, pp. 43-51, 2020

Alex. J. Agric. Sci. 